\title{
PEMANFAATAN POTENSI BUDAYA LOKAL UNTUK MENINGKATKAN KUALITAS PEMBELAJARAN IPS KELAS IV DI SEKOLAH DASAR GANDOK TIMBULHARJO SEWON BANTUL
}

\author{
Oleh: \\ Intan Kusumawati \\ Universitas Cokroaminoto Yogyakarta
}

\begin{abstract}
Abstrak
Penelitian ini bertujuan untuk mengetahui pemanfaatan potensi budaya lokal yang dapat dipakai untuk meningkatkan kualitas pembelajaran IPS di Sekolah Dasar Gandok Timbulharjo Sewon Bantul Tahun Pelajaran 2011/2012.Penelitian ini merupakan penelitian tindakan kelas partisipasif. Desain penelitian menggunakan model spiral dari Kemmis \& Taggart. Penelitian dilakukan di SD Gandok Timbulharjo Sewon Bantul dengan subjek penelitian seluruh siswa kelas IV yang berjumlah 32 orang siswa. Data dikumpulkan dengan teknik observasi, catatan lapangan, wawancara, dokumentasi, dan tes. Analisis data dengan cara kualitatif melalui langkah-langkah reduksi data, display data dan verifikasi serta disajikan menggunakan tabel dan diagram. Hasil penelitian menunjukkan bahwa pemanfaatan potensi budaya lokal selama dua siklus penelitian mampu meningkatkan kualitas pembelajaran IPS di kelas IV SD Gandok Timbulharjo Sewon Bantul. Peningkatan kualitas pembelajaran tampak dari peningkatan proses pembelajaran guru pada setiap siklus mulai dari pra pembelajaran, kegiatan awal, kegiatan inti, kegiatan akhir dan tindak lanjut pembelajaran. Pemanfaatan potensi budaya lokal juga tampak dalam proses pembelajaran baik di dalam kelas ataupun di luar kelas yaitu di Rumah Budaya Tembi Bantul. Peningkatan kualitas pembelajaran siswa terlihat dari hasil belajar siswa yang mengalami peningkatan sejumlah $75 \%$ siswa sudah baik mencapai KKM yaitu 75 . Dengan demikian peningkatan kualitas pembelajaran IPS melalui pemanfaatan potensi budaya lokal seperti sego wiwit dan uborampenya, lesung-alu, kenthongan, serta gerobag sapi menjadi sumber belajar yang bermakna bagi siswa dalam pembelajaran telah berhasil dilaksanakan oleh siswa-siswi kelas IV SD Gandok Timbulharjo Sewon Bantul.
\end{abstract}

Kata Kunci: Pemanfaatan, Potensi Budaya Lokal, Kualitas Pembelajaran IPS

\section{Pendahuluan}

Pendidikan adalah suatu proses menaburkan benih-benih budaya dan peradaban manusia yang hidup dan dihidupi oleh nilai-nilai atau visi yang berkembang dan dikembangkan dalam suatu masyarakat. Pendidikan dan kebudayaan berkenaan dengan sesuatu hal yang sama, yaitu nilai-nilai. Pendidikan juga dapat dipandang sebagai proses transmisi kebudayaan. Unsur-unsur kebudayaan melalui pendidikan meliputi nilai-nilai budaya, adat istiadat masyarakat, pandangan 
mengenai hidup, dan berbagai konsep hidup lainnya yang ada dalam masyarakat. Selain itu juga sebagai kebiasaan sosial, sikap, dan tingkah laku yang digunakan dalam interaksi atau pergaulan para anggota dalam masyarakat tersebut.

Manusia adalah makhluk yang beradab dan berbudaya. Artinya, manusia sanggup dan mampu menciptakan segala sesuatu yang bercorak luhur dan indah, yang disebut kebudayaan. Masyarakat Indonesia dikenal sebagai bangsa majemuk. Keanekaragaman Indonesia bukan saja karena terdiri dari sekitar 17.500 pulau yang dihubungkan oleh lautan, melainkan juga karena kekayaan etnis, suku, bahasa, budaya, agama dan kebiasaan. Karena kemajemukan itu, Indonesia sering dikatakan sebagai negara yang multikultural. Keunikan dan kekhasan budaya tertentu merupakan potensi yang dapat diolah untuk menembus budaya global masa kini. Oleh karena itu, kekayaan kebudayaan Indonesia tersebut perlu digali dan diperkenalkan serta dikembangkan oleh setiap manusia Indonesia. Peran pendidikan melalui sekolah menjadi penting untuk mengembangkan hal tersebut. Peran pendidikan di lembaga-lembaga pendidikan untuk mengembangkan kebudayaan tidak perlu diragukan lagi. Nilai kearifan lokal tradisional dapat dihargai kalau nilai tersebut dikenali dengan baik. Nilai-nilai kearifan budaya lokal itu jika tidak dijaga dan dipelihara, dikhawatirkan secara berangsur-angsur akan mengalami proses kepunahan. Salah satu upaya untuk menjaganya adalah melalui pemanfaatan budaya lokal dalam proses pembelajaran di sekolah.

Berkaitan dengan uraian di atas, salah satu mata pelajaran di Sekolah Dasar yang memegang peran signifikan untuk mengembangkan kebudayaan adalah pelajaran IPS. Tujuan utama pelajaran IPS di SD adalah menanamkan kesadaran akan posisi individu, baik dalam kapasitasnya sebagai pribadi maupun sebagai anggota komunitas. Pembelajaran ini bersifat strategis. Artinya, keberhasilan pembelajaran IPS di SD akan mengantarkan siswa pada situasi sadar budaya. Mereka diharapkan memiliki kesadaran bahwa dirinya tidak bisa hidup terpisah dari jaringan sosial-budaya yang lebih luas. Oleh karena itu, mereka juga harus memiliki kepribadian yang terpuji. Untuk mencapai hal itu, materi pelajaran sudah seharusnya dikembangkan berdasarkan berbagai potensi yang tersedia di sekitar kehidupan mereka.

Mata pelajaran IPS di SD sebagai salah satu mata pelajaran yang bertujuan meningkatkan dan menumbuhkan pengetahuan, kesadaran, dan sikap sebagai warganegara yang bertanggungjawab, menuntut pengelolaan pembelajaran secara dinamis dengan mendekatkan 
siswa kepada realitas objektif kehidupannya. Hal ini sudah disebutkan dalam Kurikulum Tingkat Satuan Pendidikan (KTSP) 2006, bahwa kondisi sosial budaya masyarakat setempat menjadi satu hal yang harus diperhatikan sebagai acuan operasionalnya. Artinya, kurikulum harus dikembangkan dengan memperhatikan karakteristik sosial budaya masyarakat setempat dan menunjang kelestarian keragaman budaya.

Peneliti tertarik untuk memanfaatkan potensi budaya lokal dalam pembelajaran IPS. Penelitian ini dengan judul "Pemanfaatan potensi budaya lokal untuk meningkatkan kualitas pembelajaran IPS kelas IV di SD Gandok Timbulharjo Sewon Bantul Tahun pelajaran 2011/2012”. Rumusan masalah dalam penelitian ini: Bagaimana meningkatkan kualitas pembelajaran guru IPS dan hasil belajar siswa di kelas IV di SD Gandok Timbulharjo Sewon Bantul Tahun Pelajaran 2011/2012 dengan menggunakan pemanfaatan potensi budaya lokal? Tujuan penelitian untuk mengetahui pemanfaatan potensi budaya lokal untuk meningkatkan kualitas pembelajaran guru IPS dan hasil belajar siswa kelas IV di SD Gandok Timbulharjo Sewon Bantul Tahun Pelajaran 2011/2012.

\section{Landasan Teori}

Kebudayaan berasal dari kata Sansekerta buddhayah, yaitu bentuk jamak dari budi, yang berarti akal. Kebudayaan dapat diartikan sebagai hal-hal yang bersangkutan dengan akal (Koentjaraningrat, 1990: 181). Koentjaraningrat merumuskan kebudayaan sebagai keseluruhan gagasan dan karya manusia, yang harus dibiasakannya dengan belajar, beserta keseluruhan dari hasil budi dan karyanya itu.

Budaya adalah konsep yang membangkitkan minat. Secara formal budaya oleh Deddy M (2006:18) didefinisikan sebagai tatanan pengetahuan, pengalaman, kepercayaan, nilai, sikap, makna, hirarki, agama, waktu, peranan, hubungan ruang, konsep alam semesta, objek-objek materi dan milik yang diperoleh sekelompok besar orang dari generasi ke generasi melalui usaha individu dan kelompok. Menurut Tirun Marwito (2004: 353) hakikat budaya Jawa adalah cipta, karsa, dan rasa, yang diyakini masyarakat sebagai sesuatu yang benar dan indah. Budaya Ngayogyakarta hadiningrat yang di yakini sebagai salah satu acuan dalam kehidupan bermasyarakat. 
Menurut James P.Spradley dalam (Rusmin, 2008:21) yang menyatakan "Culture is the acquired knowledge that people use to interpretation experience and to generate social behavior...we speak of them as cultural knowledge, cultural behavior, and cultural artifacts" Kebudayaan adalah pengetahuan yang diperoleh yang digunakan penduduk untuk menginterpretasikan pengalaman dan melahirkan tingkah laku sosial. Sedangkan budaya lokal adalah nilai-nilai lokal hasil budi daya masyarakat suatu daerah yang terbentuk secara alami dan diperoleh melalui proses. Budaya lokal dapat berupa hasil seni, tradisi, pola pikir, atau hukum adat. Budaya lokal biasanya didefinisikan sebagai budaya asli dari suatu kelompok masyarakat tertentu.

Belajar merupakan kegiatan yang terjadi pada semua orang tanpa mengenal batas usia dan berlangsung seumur hidup. Belajar merupakan usaha yang dilakukan seseorang melaui ineraksi dengan lingkungan untuk mengubah perilakunya. Hasil belajar adalah berupa perubahan perilaku yang relatif permanen pada diri orang yang belajar. Heinich, et al., (1996: 8) mendefinisikan belajar sebagai berikut : "learning is the development of new knowledge, skills, or attitudes as an individual interacts with information and the environment. Learning takes place all the time”. Artinya, belajar merupakan kegiatan untuk mengembangkan pengetahuan baru, keterampilan, atau perilaku, sebagai bentuk interaksi individu dengan informasi dan lingkungan belajar bisa terjadi di mana pun dan kapan pun.

Menurut Oemar Hamalik (2009: 46) pengajaran berdasarkan pengalaman menyediakan suatu alternatif pengalaman belajar bagi siswa yang lebih luas daripada pendekatan yang diarahkan oleh guru kelas. Strategi ini menyediakan banyak kesempatan belajar secara aktif, personalisasi, dan kegiatan-kegiatan belajar lainnya bagi para siswa untuk semua tingkat usia. Pengajaran berdasarkan pengalaman memberikan kepada siswa seperangkat atau serangkaian situasi pendidikan dalam bentuk keterlibatan pengalaman senyatanya, yang sengaja diciptakan oleh guru.

Kualitas Pembelajaran adalah determinan dari mutu pendidikan. Kualitas pembelajaran ditentukan oleh strategi pembelajaran yang dirancang, dikelola, dan dinilai. Makin tinggi keterlibatan peserta didik dengan guru dan objek belajar, maka proses belajar akan semakin berkualitas. Oleh karena itu, upaya untuk meningkatkan kualitas pembelajaran dapat dilakukan 
dengan cara mengoptimalkan semua komponen dalam pembelajaran. Keterlibatan peserta didik sebagai subjek dalam pembelajaran merupakan hal yang penting.

Pembelajaran yang berkualitas dapat dicapai dengan cara memanfaatkan komponenkomponen pembelajaran, selain itu juga diperlukan kemampuan guru dalam melaksanakan pembelajaran sesuai dengan kompetensi guru, yaitu kemampuan memilih dan menggunakan media yang tepat, dan kemampuan mengelola pembelajaran, serta penggunaan strategi pembelajaran yang optimal untuk mencapai tujuan pembelajaran. Ini berarti, bahwa untuk mencapai kualitas pembelajaran yang tinggi, materi pembelajaran harus diorganisasikan melalui strategi pengorganisasian yang tepat dan selanjutnya disampaikan kepada peserta didik. Pembelajaran dikatakan berkualitas jika hasil belajar siswa meningkat. Hasil belajar dapat dimaknai sebagai perubahan tingkah laku yang diperoleh dari proses pembelajaran tersebut, baik dalam aspek kognitif, afektif, maupun psikomotor (Nana Sudjana, 2001: 8).

Proses pembelajaran dikatakan berhasil dan berkualitas apabila masukannya merata, menghasilkan output yang banyak dan bermutu tingggi, serta sesuai dengan kebutuhan, perkembangan masyarakat dan pembangunan. Untuk mencapai tuntutan tersebut, maka perlu dikembangkan pengalaman belajar yang kondusif untuk membentuk manusia yang berkualitas tinggi, baik mental, moral atau sosial, maupun fisik. Kriteria yang biasa digunakan dalam menilai proses belajar mengajar menurut Nana Sudjana (2005: 60-61) antara lain adalah: Konsistensi kegiatan belajar mengajar dengan kurikulum, Keterlaksanaannya oleh guru, Keterlaksanaannya oleh siswa, Memotivasi belajar siswa, Keaktifan para siswa dalam kegiatan belajar dan Interaksi guru siswa.

\section{Metode Penelitian}

Penelitian ini dilakukan di kelas IV SD Gandok Timbulharjo Sewon Bantul pada Mata Pelajaran IPS. Waktu Pelaksanaan : Bulan Juli, Agustus dan September 2011. Subjek penelitian adalah seluruh siswa Kelas IV (empat) SD Gandok Timbulharjo Sewon Bantul sebanyak 32 siswa yang terdiri dari 16 siswa perempuan dan 16 siswa laki-laki.

Penelitian ini merupakan Penelitian Tindakan Kelas Partisipatif yang memfokuskan pada upaya peningkatan kualitas pembelajaran IPS Sekolah Dasar Gandok Timbulharjo Sewon Bantul. Peneliti terlibat langsung dalam proses penelitian sejak awal sampai akhir proses 
penelitian. Penelitian ini bertujuan untuk meningkatkan kualitas pembelajaran Sekolah Dasar Kelas IV SD Gandok melalui Pemanfaatan Potensi Budaya Lokal dan bagaimana upaya yang dilaksanakan guru dalam proses pembelajaran IPS agar dapat meningkatkan kualitas pembelajaran, kaitannya dengan pemanfaatan potensi budaya lokal. Desain penelitian tindakan kelas ini menggunakan metode spiral atau Siklus dari Kemmis dan Taggart dalam Suharsimi Arikunto (1990: 92) setiap siklus memuat empat tahapan yaitu: (1) Perencanaan, (2) Pelaksanaan, (3) Observasi, dan (4) Refleksi. Keempat tahapan tersebut dilakukan berdasarkan hasil diskusi bersama antara peneliti dan guru pelaksana. Analisis data dalam penelitian ini dilakukan secara deskriptif untuk melukiskan hasil pengamatan. Proses analisa data dilakukan melalui reduksi data, penyajian data dan verifikasi seperti yang dikemukan oleh Sugiyono (2009: 337).

\section{Hasil Penelitian dan Pembahasan}

\section{A. Hasil Penelitian}

\section{Observasi awal}

Observasi awal dilakukan dengan tujuan untuk mengetahui permasalahan yang dihadapi guru dalam pembelajaran IPS di kelas yang menjadi subjek penelitian. Kualitas pembelajaran yang menjadi fokus penelitian ini adalah aktivitas yang dilakukan guru dan partisipasi siswa baik dalam kelompok maupun dalam proses pembelajaran.

\section{Siklus I}

\section{a. Rencana Tindakan}

Pada Siklus I ini, tahapan penelitian yang dilakukan ada empat, yaitu perencanaan, pelaksanaan, observasi dan refleksi. Alokasi waktu pembelajaran satu kali tatap muka setiap minggu, yaitu setiap hari Kamis pukul 07.00 - 08.30 WIB.

\section{b. Pelaksanaan Tindakan}

Tindakan pada siklus I dilaksanakan selama 3 kali pertemuan, dengan alokasi waktu 105 menit setiap pertemuan. Pada awal dan akhir siklus dilakukan tes (pre test dan post test) untuk mengetahui dan mengukur peningkatan hasil belajar siswa setelah memanfaatkan potensi budaya lokal dalam kegiatan pembelajaran IPS. 


\section{c. Observasi Tindakan}

Pengamat melakukan observasi untuk mengamati proses pembelajaran guru IPS. Berdasarkan hasil pengamatan untuk 24 pernyataan penilaian kinerja guru IPS diperoleh skor penilaian kinerja guru IPS pada Siklus I pertemuan 1 (satu) dengan skor 2,29 termasuk kategori cukup baik (skor 2,29 berada di antara $>1,75-2,50$ ) dikatakan penilaian kinerja guru IPS sudah cukup baik. Skor penilaian kinerja guru IPS pada Siklus I pertemuan 2 (dua) dengan skor 2,58 termasuk kategori cukup baik (skor 2,58 berada diantara $>2,50-3,25$ ) dikatakan penilaian kinerja guru IPS sudah baik. Skor penilaian kinerja guru IPS pada Siklus I pertemuan 3 (tiga) dengan skor 2,95 termasuk kategori sudah baik (skor 2,95 berada diantara $>2,50-3,25)$ dikatakan penilai kinerja guru IPS sudah baik. Dengan penilaian kinerja guru tersebut terjadi peningkatan proses pembelajaran dari proses pembelajaran guru IPS yang dikatakan cukup baik menjadi kategori sudah baik. Selama siklus I diadakan pre test dan post test untuk mengukur tingkat penguasaan materi IPS siswa kelas IV SD Gandok Timbulharjo Sewon Bantul. Data hasil Pre Test dan Post Test yang diperoleh setelah satu siklus tindakan.Telah terjadi peningkatan jumlah siswa yang mencapai batas Ketuntasan Belajar pada mata pelajaran IPS sesuai kriteria keberhasilan, yaitu 75. Jumlah siswa yang mendapatkan nilai $\leq 75$ pada saat pre test sangat banyak, yaitu 27 siswa $(84,4 \%)$. Jumlah ini menurun sekitar $35 \%$ menjadi 16 siswa (50\%). Hal ini berbanding terbalik dengan siswa yang mendapat nilai $>75$. Jika pada saat pre test hanya 5 siswa $(15,6 \%)$ yang bisa masuk kategori skor ini, maka pada saat post test sejumlah 16 siswa $(52,6 \%)$ berhasil menunjukkan kemampuan yang baik. Dengan demikian, hanya sekitar 50\% siswa yang mengalami peningkatan penguasaan materi dengan diterapkannya satu siklus penelitian tindakan kelas.

\section{d. Refleksi}

Berdasarkan observasi yang dilakukan selama tindakan berlangsung, selanjutnya peneliti berkolaborasi dengan guru pelaksana dan pengamat melakukan refleksi. Refleksi dilakukan berdasarkan data-data yang diperoleh, aktivitas guru dan siswa, serta pre test dan post test. Refeksi dilakukan dengan cara mengevaluasi tindakan pembelajaran IPS dengan memanfaatkan potensi budaya lokal selama siklus I. 


\section{Siklus II}

\section{a. Rencana Tindakan}

Untuk meningkatkan kualitas pembelajaran IPS, baik segi proses maupun hasilnya, peneliti dan guru pelaksana memperbaiki perencanaan tindakan siklus II. Apabila pada siklus I selama tiga kali pertemuan siswa belajar di kelas saja dengan media gambar yang sudah disesuaikan dengan potensi budaya lokal masyarakat Kecamatan Sewon Bantul maka pada siklus II siswa diajak belajar langsung dari alam dan lingkungan.

\section{b. Pelaksanaan Tindakan}

Tindakan pada siklus II dilaksanakan selama 5 kali pertemuan, dengan alokasi waktu sama dengan siklus I yaitu 105 menit setiap pertemuan.

\section{c. Observasi Tindakan}

Pelaksanaan pembelajaran IPS di kelas IV SD Gandok Timbulharjo Sewon Bantul dengan memanfaatkan potensi budaya lokal pada siklus II ini sudah sesuai dengan perencanaan yang telah disusun. Aktivitas belajar siswa sudah cukup bervariasi, tidak hanya sekedar mendengarkan nasehat dari guru dan mengerjakan tugas yang diberikan. Selama lima kali pertemuan dalam siklus II ini, siswa terlihat aktif dalam proses pembelajaran secara keseluruhan, mulai dari kegiatan pra pembelajaran sampai pada kegiatan akhir.

Berdasarkan hasil pengamatan untuk 24 pernyataan penilaian kinerja guru IPS diperoleh skor penilaian kinerja guru IPS pada Siklus II yang terdiri dari 5 kali pertemuan. Pertemuan 1 (satu) dengan skor 3,16 termasuk kategori baik (skor 3,16 berada di antara $>2,50-3,25)$ dikatakan penilaian kinerja guru IPS sudah baik. Skor penilaian kinerja guru IPS pada Siklus II pertemuan 2 (dua) dengan skor 3,29 termasuk kategori sangat baik (skor 3,29 berada diantara $>3,25-4,00$ ) dikatakan penilaian kinerja guru IPS sudah sangat baik. Skor penilaian kinerja guru IPS pada Siklus II pertemuan 3 (tiga) dengan skor 3,37 termasuk kategori sangat baik (skor 3,37 berada diantara $>3,25-4,00$ ) dikatakan penilai kinerja guru IPS sudah sangat baik. Skor penilaian kinerja guru IPS pada Siklus II pertemuan 4 (empat) dengan skor 3,41 termasuk kategori sangat baik (skor 3,41 berada diantara $>3,25-4,00$ ) dikatakan penilaian kinerja guru IPS sudah sangat baik. Pada awal dan akhir siklus II terjadi 
peningkatan penguasaan materi IPS dan jumlah siswa yang mencapai batas ketuntasan belajar pada mata pelajaran IPS sesuai kriteria keberhasilan (KKM), yaitu 75.

\section{d. Refleksi}

Refleksi dilakukan dari data-data yang diperoleh dari aktivitas guru, serta pre test dan post test. Refeksi dilakukan dengan mengevaluasi tindakan pembelajaran IPS dengan memanfaatkan potensi budaya lokal selama siklus II.

\section{Pembahasan Hasil Penelitian}

\section{Proses Pembelajaran}

Upaya untuk meningkatkan kualitas pembelajaran dapat dilakukan dengan cara mengoptimalkan semua komponen dalam pembelajaran. Dalam proses belajar pada tindakan siklus I dan siklus II siswa selalu dilibatkan dan diberi kesempatan untuk melakukan aktivitas belajar. Keterlibatan siswa bukan hanya secara fisik, tetapi juga secara mental dan sosial. Melalui aktivitas belajar dalam kelompok, siswa saling bekerja sama dengan cara saling menghargai kontribusi teman dalam menyelesaikan tugas yang diberikan guru. Apabila dilihat dari proses pembelajaran dan hasil observasi, menunjukkan bahwa proses interaksi antara siswa dengan siswa dalam satu kelompok maupun antar kelompok terjadi melalui kegiatan kerja kelompok. Secara keseluruhan, suasana pembelajaran yang dilakukan, baik di kelas maupun di luar kelas, sangat menyenangkan dan mampu merangsang keaktifan siswa untuk belajar.

Keberhasilan proses pembelajaran akibat dari penggunaan multi metode yang digunakan oleh guru. Variasi metode yang mampu mengoptimalkan pembelajaran IPS dalam kegiatan belajar siswa yang digunakan dalam penelitian ini. Rencana pelaksanaan pembelajaran yang memuat langkah-langkah pembelajaran mengalami perubahan dari siklus I ke siklus II. Pada siklus I, tiga kali tatap muka dilaksanakan dengan metode ceramah, diskusi, dan permainan dan proses pembelajarannya hanya dilakukan di dalam kelas. Penggunaan ketiga metode tersebut sudah mampu meningkatkan kualitas proses pembelajaran dan hasil pembelajaran. Sementara itu, pada siklus II, selain menggunakan ketiga metode tersebut, juga digunakan metode studi lapangan. Siswa diajak belajar secara langsung tentang materi yang sebelumnya sudah mereka pelajari secara langsung tentang 
materi yang sebelumnya sudah mereka pelajari secara teori di dalam kelas. Proses pembelajaran untuk siklus II selain dilakukan di dalam kelas, juga dilakukan di luar kelas, yaitu dengan mengajak siswa ke lingkungan sekitar yakni di area pertanian, perkebunan, perikanan dan Rumah Budaya Tembi Timbulharjo Sewon Bantul.

Pembelajaran IPS di Sekolah Dasar diharapkan dapat mengembangkan berbagai kemampuan pada diri siswa, khususnya kemampuan pada diri siswa, khususnya kemampuan untuk hidup di tengah-tengah lingkungan atau masyarakat tempat tinggal siswa. Pembelajaran IPS di Sekolah Dasar dapat berlangsung efektif apabila siswa dapat berinteraksi langsung dengan obyek, peristiwa, situasi dan kondisi kehidupan sehari-hari melalui sumber belajar. Proses pembelajaran harus dapat memberi kesempatan kepada siswa untuk mampu mengembangkan potensinya secara optimal, sehingga dalam proses pembelajaran terjadi transfer of learning, transfer of training, dan transfer of principles. Untuk mewujudkan hal tersebut, peneliti telah mengembangkan media pembelajaran berbasis budaya lokal dalam bentuk gambar yang disesuaikan dengan pokok bahasan dan konteks kehidupan masyarakat Kecamatan Sewon Bantul.

\section{Hasil Pembelajaran}

Pembelajaran IPS melalui pemanfaatan potensi budaya lokal telah menunjukkan hasil yang memuaskan dan menggembirakan. Hasil belajar kognitif kognitif dapat dilihat dari nilai tes siswa, baik pre test maupun post test yang sudah dilakukan pada setiap siklus. Nilai tes tersebut menunjukkan bahwa setiap siswa mengalami peningkatan hasil belajar yang cukup signifikan. Sesuai dengan data yang didapat, bahwa dengan melihat hasil belajar siswa selama dua siklus dapat disimpulkan bahwa tujuan pembelajaran telah berhasil. Pada awal siklus I, rerata nilai siswa adalah 63,8. Sementara itu, pada akhir siklus II rerata nilai siswa naik menjadi 83,5. Dengan demikian, apabila dilihat dari hasil belajar kedua siklus menunjukkan bahwa siswa telah berhasil mencapai kompetensi pembelajaran. Dari kedua siklus yang dilaksanakan, hanya enam siswa saja yang tidak berhasil mencapai kompetensi minimal pada akhir siklus II. Keenam siswa tersebut, yaitu siswa yang bernomor urut 6, 7, 8, 17, 29 dan 31. Dari keenam siswa yang tidak berhasil mencapai kompetensi minimal tersebut, empat orang siswa mendapat nilai 73, yaitu siswa dengan nomor urut 7, 17, 29 dan 31. Sementara itu, kedua siswa yang lain yang bernomor urut 6 dan 8 mendapatkan nilai 67. Untuk keempat 
siswa yang mendapatkan nilai 73 , peneliti sekaligus guru pelaksana menganggap bahwa keempatnya telah berhasil, walaupun nilai yang diperoleh belum mencapai kriteria keberhasilan yang ditetapkan, yaitu 75 (hanya kurang 2 poin). Akan tetapi, untuk kedua siswa dengan nilai 67, keduanya dianggap belum berhasil karena nilai yang diperoleh cukup jauh selisihnya dari kriteria keberhasilan. Setelah dilakukan trianggulasi dengan data hasil observasi dan dokumentasi nilai. keduanya memang memiliki kemampuan yang kurang dibanding siswa lain. Sementara itu, hasil belajar berupa aspek psikomotor juga dapat lebih ditingkatkan setelah dua siklus tindakan. Selain melalui pembelajaran di kelas, pembelajaran di luar kelaspun melalui studi lapangan bermanfaat bagi siswa untuk mendayagunakan dan mengaplikasikan konsep yang telah dipelajari di kelas.

\section{Kesimpulan dan Saran}

\section{Kesimpulan}

Peningkatan kualitas pembelajaran IPS dengan memanfaatkan potensi budaya lokal dapat dilihat dari peningkatan kualitas pembelajaran guru pada setiap siklusnya yang dari pra pembelajaran, kegiatan awal, kegiatan inti, kegiatan akhir dan tindak lanjut pembelajaran sudah sangat baik. Kualitas pembelajaran juga dilihat dari hasil belajar siswa kelas IV telah terjadi peningkatan sejumlah 75\% siswa sudah baik mencapai KKM yaitu 75 .

\section{Saran}

1. Guru diharapkan dapat mencoba menerapkan pembelajaran IPS dengan memanfaatkan potensi budaya lokal pada pokok bahasan yang lain, sehingga fungsi strategis pelajaran ini, yaitu mendekatkan siswa dengan kesehariannya bisa terwujud.

2. Guru diharapkan dapat menerapkan pembelajaran IPS dengan memanfaatkan potensi budaya lokal sehingga pembelajaran menjadi tidak sekedar tekstual, tetapi lebih konstektual.

3. Guru diharapkan dapat menerapkan pembelajaran IPS dengan memanfaatkan potensi budaya lokal sehingga kualitas pembelajaran, baik proses maupun hasilnya menjadi meningkat. 


\section{Daftar Pustaka}

Adhiputra. (2001). Pengembangan model layanan bimbingan berbasis nilai budaya lokal untuk meningkatkan kreativitas anak: Suatu studi pada siswa di SD di Kota Denpasar Bali. Badung, University Pendidikan Indonesia.

Agung Iskandar. (2010). Meningkatkan kreativitas pembelajaran bagi guru. Jakarta. Penerbit: Bestari Buana Murni.

Allyn \& Bacon. (1989). Learning and teaching: Research based methods, AS

Baharuddin \& Wahyuni Esa Nur. (2010). Teori belajar dan pembelajaran. Yogyakarta: Ar-Ruzz Media.

DPR RI. (2003). Undang-Undang Republik Indonesia No.20 Tahun 2003 tentang Sistem Pendidikan Nasional.

Eko Putro Widoyoko. (2014). Penilaian hasil pembelajaran di sekolah. Yogyakarta: Pustaka Pelajar.

Ely Julia. (2005). Peran budaya lokal dalam pembentukan sains: Studi naturalistik pembentukan sains siswa kelompok budaya Sunda tentang fotosintesis dan respirasi tumbuhan dalam konteks sekolah dan lingkungan pertanian. Bandung, Universitas Pendidikan Indonesia.

Gatut Murniatmo, dkk. (2000). Khazanah budaya lokal: Sebuah pengantar untuk menahami kebudayaan daerah di nusantara. Penerbit: Adicita Karya Nusa. Yogyakarta.

Kemmis, S., \& Taggart Mc. (1990). The action research planner. Victoria: Deakin University. Koentjaraningrat. (1990). Pengantar ilmu antropologi. Jakarta: Rineka Cipta.

Mulyana Deddy \& Jalaluddin Rahmad (Ed). (2006). Komunikasi antar budaya: Panduan berkomunikasi dengan orang-orang berbeda budaya. Bandung: Remaja Rosdakarya.

Munandar Soelaeman, M. (1987). Ilmu budaya dasar suatu pengantar. Bandung: Eresco.

Numan Somantri. (2001). Menggagas pembaharuan pendidikan IPS. Bandung: Remaja Rosdakarya. 